KAWISTARA

VOLUME 3

No. 2, 17 Agustus 2013

Halaman 117-226

\title{
KAPASITAS DAYA DUKUNG FISIK DAN LINGKUNGAN OPTIMAL SEBAGAI DAYA DUKUNG KEPARIWISATAAN ALAM YOGYAKARTA UTARA SETELAH PASCAERUPSI MERAPI 2010
}

\author{
Muhamad \\ Program Studi Kajian Pariwisata \\ Sekolah Pascasarjana Universitas Gadjah Mada \\ Email: memet_andra@yahoo.com
}

\begin{abstract}
This study is intended to determine how likely the surge of tourists who come to visit the center of tourist attraction objects specific in north Yogyakarta region post-eruption after 2010. This was carried out to reduce the excessive density of visitors to the area a tourist attraction after the object after the eruption of 2010. A high number of visits directly or indirectly will result in interference with ecosystems, and can even damage the environment. It is therefore necessary analysis to determine the safety guidelines with regard to the issue. On the other hand, the level of comfort of the travelers will also be reduced if there is a high density. It is necessary for tolerance analysis and physical competence capacity optimally at tourism sites. Results of the analysis showed that the distribution of visitors is uneven and concentrated only in certain point of tolerance and capacity are very limited physical abilities. The ability of the region to determine the optimal physical tolerance limits that still allow capacity flexibly so that its longterm goals, is the fulfillment of the level of flexibility and satisfaction for tourists.
\end{abstract}

Keywords: Optimal Physical Abilities, Carrying Capacity, Tourism Nature.

\begin{abstract}
ABSTRAK
Kajian ini dimaksudkan untuk mengetahui seberapa besar kemungkinan terjadinya lonjakan wisatawan yang datang ke pusat kunjungan obyek daya tarik wisata (ODTW) tertentu di wilayah Yogyakarta utra setelah pasca-erupsi 2010. Hal ini diupayakan untuk mereduksi terjadinya kepadatan pengunjung secara berlebihan pada kawasan obyek daya tarik wisata setelah pasca erupsi 2010. Jumlah kunjungan yang tinggi secara langsung maupun tidak langsung akan mengakibatkan gangguan pada ekosistem lingkungan, dan bahkan dapat merusak lingkungan. Oleh karena itu diperlukan analisis untuk menentukan rambu-rambu pengaman berkenaan dengan masalah tersebut. Pada sisi yang lain, tingkat kenyamanan para wisatawan juga akan berkurang apabila terjadi kepadatan yang tinggi. Untuk itu perlu dilakukan analisis toleransi dan kapasitas kemampuan fisik secara optimal pada kepariwisataan alam. Hasil analisis menunjukan bahwa sebaran pengunjung tidak merata dan hanya terkonsentrasi di titik tertentu yang toleransi dan kapasitas kemampuan secara fisik sangat terbatas. Kemampuan fisik optimal kawasan dapat menentukan batas toleransi kapasitas yang masih memungkinkan secara fleksibel sehingga tujuan jangka panjangnya, adalah terpenuhinya tingkat keleluasaan dan kepuasan bagi wisatawan.
\end{abstract}

Kata Kunci: Kemampuan Fisik Optimal, Daya Dukung, Kepariwisataan Alam 


\section{PENGANTAR}

Setelah erupsi Merapi 2010 obyek-obyek wisata yang berada di wilayah Yogyakarta bagian utara mengalami berbagai gradasi lingkungan beserta daya tarik wisata serta potensi-potensi wilayahnya, sehingga menimbulkan dampak yang tidak sedikit. Akan tetapi, wilayah Yogyakarta utara masih menjadi destinasi utama. Kajian ini mencoba untuk menggali kembali potensi kepariwisataanalam di wilayah tersebut. Salah satunya dengan menggali kembali potensi kepariwisataan alam melalui kapasitas fisik dan lingkungan optimal sebagai daya dukung kawasan kepariwisataan alam.

Kegiatan kepariwistaan alam sebagai potensi andalan bagi devisa negara, dalam kegiatannya menuntut perencanaan yang matangsejak dini.Halinimerupakantindakan operasional yang diimplementasikan mulai dari tingkat pusat, provinsi, dan kabupaten. Salah satu yang menjadi prioritas adalah kawasan kepariwisataan alam yang berada di wilayah Yogyakarta Utara. Upaya tersebut pada dasarnya merupakan tahapan implementasi UU No 10 Tahun 2009 tentang kepariwisataan yaitu prinsip-prinsip pembangunan berkelanjutan (sustainable development) di bidang kepariwisataan alam.

Wilayah Yogyakarta Utara menjadi salah satu obyek daya tarik wisata (ODTW) unggulan di kabupaten Sleman karena kondisi lingkungan alamnya yang unik dan eksotis. Potensi tersebut berupa kualitas berbagai obyek alam yang sangat indah dengan komponen fisik pegunungan, bukit, lembah, hutan, danau, air terjun dari pegunungan, dan desa wisata. Kualitas atraksi inilah yang kemudian menjadikan tingginya minat wisatawan berkunjung ke wilayah Yogyakarta Utara. Maka dari itu, dapat dipastikan kunjungan ke wilayah Yogyakarta Utara akan mencapai jumlah yang signifikan tinggi dan inilah yang perlu mendapat perhatian.

Jumlah kunjungan yang tinggi secara langsung maupun tidak langsung akan mengakibatkan gangguan pada ekosistem lingkungan, bahkan dapat merusak lingkungan tersebut. Selain gangguan lingkungan obyek daya tarik wisata akan mengalami penurunan kualitas atau teriritasi dan tercemar. Oleh karena itu, diperlukan analisis untuk menentukan rambu-rambu pengaman berkenaan dengan masalah tersebut.

Pada sisi yang lain, tingkat kenyamanan para wisatawan juga akan berkurang apabila terjadi kepadatan yang tinggi (Gunn. C.A., 1994). Untuk itu perlu dilakukan analisis daya dukung kawasan (fisik) yang dapat menentukan batas toleransi kapasitas yang masih memungkinkan secara fleksibel. Tujuan jangka panjangnya adalah terpenuhinya kepuasan pengunjung. Untuk memenuhi implementasi tujuan jangka panjang ini, maka ditetapkan fokus kajian dengan topik kajian kapasitas fisik lingkungan optimal sebagai daya dukung kawasan kepariwisataan alam di wilayah Yogyakarta utara setelah pascaerupsi 2010.

Berdasarkan hasil observasi lapangan di kawasan Yogyakarta Utara telah diperoleh informasi obyek daya tarik wisata alam yang potensial untuk dikembangkan. Secara umum terdapat pada 1 (satu) kawasan Yogyakarta utara yaitu di kawasan kaliurang di Kecamatan Pakem dan kecamatan Cangkringan. Kawasan tersebut hingga saat ini masih memiliki daya tarik bagi pengunjung secara terpusat di beberapa lokasi. Artinya, masih terdapat kawasan yang kurang menarik wisatawan. Terkait dengan kajian kapasitas fisik kawasan (carrying capacity) optimal, maka dalam analisis nantinya akan lebih difokuskan pada kawasan yang menjadi pusat kunjungan.

Kawasan yang belum menghasilkan kunjunganyang signifikan, akan menggunakan hasil analisis kawasan yang menjadi pusat kunjungan. Artinya, hasil analisis pada pusat kunjungan akan diasumsikan sama untuk membatasi jumlah pengunjung pada kawasan yang belum menghasilkan kunjungan secara signifikan. Asumsi ini dapat difungsikan pada masa yang akan datang, khususnya bila kawasan yang belum dikunjungi tersebut telah sukses dipromosikan dan menjadi kawasan unggulan. Untuk itu, bagaimana daya dukung 
fisik beserta sarana dan prasarana kawasan di Yogyakarta Utara sangat berpengaruh terhadap tingkat kenyamanan para wisatawan.

\section{Kerangka Toleransi dan Kapasitas Daya Dukung Fisik Wilayah Yogyakarta utara.}

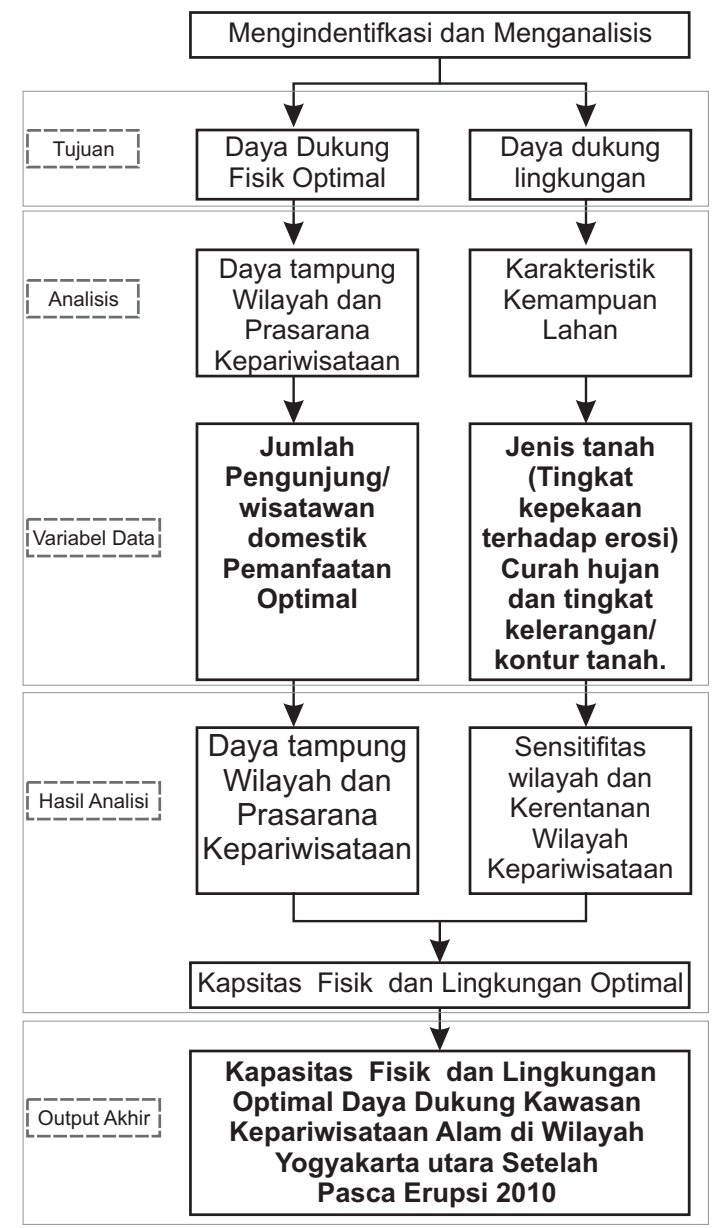

Gambar 1

Skema Kapasitas Fisik dan Lingkungan Optimal di Kawasan Kepariwisataan Alam Sumber: Analisis peneliti, 2011

Secara geografis wilayah Kabupaten Sleman terletak di antara $107^{\circ} 15^{\prime} 0^{\prime \prime}$ Bujur Timur, $7^{\circ} 34^{\prime} 51^{\prime \prime}$ dan $7^{0} 47^{\prime}$ 03" Lintang Selatan merupakan wilayah perbukitan dan pegunungan yang membentang hingga lereng Gunung Merapi dengan ketinggian antara 100 meter hingga 2.500 meter di atas permukaaan laut. Wilayah bagian Selatan relatif datar kecuali perbukitan di sebelah tenggara yaitu Kecamatan Prambanan dan di sebelah barat daya, yaitu sebagian Kecamatan Gamping. Semakin ke utara kondisi lahan semakin bergelombang. Pada bagian Utara wilayah Sleman (Lereng Gunung Merapi) kondisi alam relatif terjal, tetapi tingkat kesuburannya tinggi dan terdapat banyak sumber air.

Wilayah yang berada di lereng Gunung Merapi merupakan daerah resapan air dan sumber air bersih bagi wilayah DIY dan Kabupaten Klaten. Keadaan Alam tersebut mengakibatkan semua kegiatan pembangunan di Kabupaten Sleman secara langsung memengaruhi perkembangan dan pertumbuhan kabupaten atau kota yang lain di DIY.

Pengembangan Kabupaten Sleman yang terletak di wilayah utara dan sebagai bagian integral dari Provinsi Daerah Istimewa Yogyakarta sebagai kota pendidikan dan budaya, maka Kabupaten Sleman diarahkan sebagai pusat pendidikan, pusat kebudayaan, penghasil pangan, daerah tujuan wisata, pengembangan industri kecil, agro industri, dan industri jasa yang meliputi beberapa wilayah berikut ini.

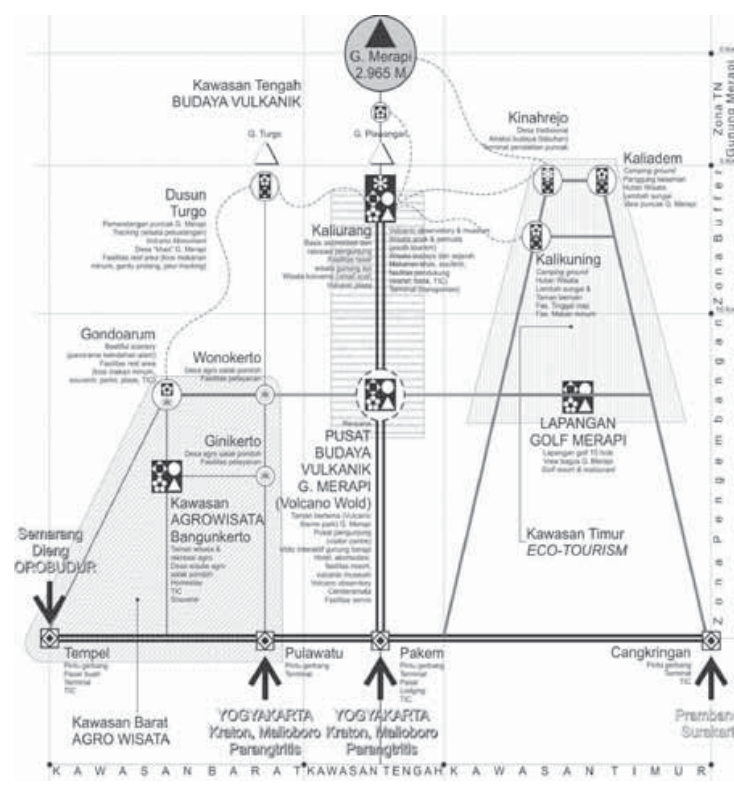

Gambar 2

Peta Lingkup Wilayah Penelitian di Utara Sumber: Analisis Peneliti 2013 
Pada saat ini kegiatan wisata alam di alam terbuka yang nyaman dan masih alami makin banyak dikunjungi wisatawan. Meningkatnya kegiatan wisata ini ada kaitannya dengan perubahan pola hidup masyarakat, meningkatnya taraf kehidupan, adanya pertambahan waktu luang, serta semakin meningkatnya fasilitas sarana, dan prasarana sehingga dapat menjangkau tempat-tempat tujuan wisata. Obyek wisata alam yang ada di Indonesia dikelompokkan menjadi dua obyek wisata alam, yaitu obyek wisata yang terdapat di luar dan di dalam kawasan konservasi, terdiri dari taman nasional, taman wisata, taman buru, taman laut, dan taman hutan raya.

Menurut Soemarwoto (2004) produk utama pariwisata adalah lingkungan itu sendiri. Suatu alasan empiris; Pearce (1996) dan Maryani (2002) menyebutkan bahwa wisatawan datang untuk menikmati iklim, pemandangan indah, budaya masyarakat, serta produk-produk buatan manusia. Bila lingkungan rusak, maka secara otomatis nilai aset menjadi menurun, kemudian tidak akan disukai oleh wisatawan untuk masa selanjutnya. Untuk itu, daya dukung kawasan sebagai suatu perencanaan awal mutlak dilakukan.

Mengadaptasi pola fikir dari UndangUndang No. 23 Tahun 1997 bahwa daya dukung kawasan pariwisata merupakan kemampuan tertentu suatu kawasan untuk menerima wisatawan. Lebih lanjut, Soemarwoto (2004) menjelaskan daya dukung kawasan adalah kapasitas fisik tertentu pada suatu daerah untuk menerima wisatawan atau jumlah wisatawan maksimal yang dapat memanfaatkan suatu kawasan tanpa menimbulkan penurunan kualitas lingkungannya. Terkait dengan konteks daya dukung ini, menurut Fandeli dan Muhammad (2009) hal yang memengaruhi daya dukung kawasan pariwisata salah satunya adalah faktor lingkungan biofisik lokasi wisata.

Eplerwood, 1999 menyebutkan beberapa prinsip tentang kapasitas fisik dan lingkungan. Pada umumnya lingkungan alam mempunyai kapasitas fisik yang lebih rendah dengan kapasitas fisik kawasan buatan. Meskipun mungkin permintaan sangat banyak, tetapi daya dukunglah yang membatasi.

Apabila kapasitas fisik diperhitungkan, maka dapat diperoleh angka berapa luas areal yang dibutuhkan bagi wisatawan untuk secara leluasa dan memuaskan dalam berwisata. Menurut Douglass (1975) penetapkan area untuk berkemah adalah 4-8 orang/are dan area untuk berpiknik adalah 13-16 orang/ are. Daya dukung pariwisata diperhitungkan agar wisatawan memperoleh kepuasan. Kepuasan pengguna jasa didekati dengan menetapkan daya dukung fisik (physical carrying capacity).

Kapasitas daya dukung secara fisik mengandung pengertian kemampuan suatu tempat dalam menunjang kehidupan mahluk hidup secara optimum dalam periode waktu yang panjang. Daya dukung lingkungan dapat pula diartikan kemampuan lingkungan memberikan kehidupan organisme secara sejahtera dan lestari bagi penduduk yang mendiami suatu kawasan.

Rata-rata kepadatan suatu populasi atau ukuran populasi dari suatu kelompok manusia di bawah angka yang diperkirakan akan meningkat di atas angka yang diperkirakan untuk menurun disebabkan oleh kekurangan sumber daya. Kapasitas pembawa akan berbeda untuk tiap kelompok manusia dalam sebuah lingkungan tempat tinggal, disebabkan oleh jenis makanan, tempat tinggal, dan kondisi sosial dari masing-masing lingkungan tempat tinggal tersebut.

Lingkungan dan ekosistem yang kuat mempunyai daya dukung yang tinggi; misalnya di lokasi yang landai dengan ketinggian yang rendah dari permukaan, dan tanah yang subur. Tanah yang datar dan landai tidak mudah tererosi, jika terjadi kerusakan tanaman akan dapat pulih kembali karena suhu dari tanah yang menunjang. Akan tetapi, sebaliknya keadaan fisik seperti di dataran tinggi atau di pegunungan dengan suhu yang rendah, dan tanah yang miring; ada kalanya memiliki ekosistem yang rapuh. Ekosistem ini akan mudah terganggu karena banyaknya pengunjung. 
Selain faktor fisik, menurut Soemarwoto (2004) dan Gun (Douglas 1975) daya dukung kawasan pariwisata juga berkaitan dengan faktor psikologis wisatawan. Secara umum, kawasan pegunungan yang memiliki hawa sejuk, rata-rata wisatawan mencari nilai-nilai keheningan, jauh dari hiruk pikuk polusi suara, dan rendahnya tingkat kepadatan manusia. Semuanya ini merupakan nilai dari sebuah kenyamanan berwisata. Berdasarkan atas pendapat Fandeli dan Muhammad (2009) dan Soemarwoto (2004) tersebut, maka perencanaan pengembangan pariwisata haruslah memperhatikan daya dukung kawasan. Uraian dan penjelasan di atas, disimpulkan bahwa pentingnya mengetahui daya dukung suatu kawasan pariwisata.

Berdasarkan Undang-Undang No. 23 Tahun 1997 tentang Pengelolaan Lingkungan Hidup bahwa daya dukung kawasan pariwisata merupakan kemampuan tertentu suatu kawasan untuk menerima wisatawan. Lebih lanjut, menurut Fandeli, dan Muhammad (2009), kapasitas fisik kawasan adalah kemampuan tertentu pada suatu daerah untuk menerima wisatawan atau jumlah wisatawan maksimal yang dapat memanfaatkan suatu kawasan tanpa menimbulkan penurunan kualitas lingkungannya.

Berdasarkan definisi operasional tersebut di atas, dapat diambil poin penting yang selanjutnya menjadi variabel analisis, yaitu jumlah pengunjung/wisatawan, luas pemanfaatan optimal. Untuk implementasi analisis daya dukung kawasan pada kajian ini, mekanisme yang digunakan dengan menghitung daya tampung kawasan berdasarkan data jumlah wisatawan yang tercatat dalam statistik kunjungan pengunjung perbulan. Mengingat dalam kegiatan rekreasi, wisatawan membutuhkan prasarana, maka variabel prasarana wisata juga akan dianalisis.

Douglass (1975) memperhitungkan kebutuhan area untuk aktivitas wisatawan berdasarkan faktor pemulihan atau keterbalikan (Turnover Factor /TF). Jenis aktivitas dan luasan yang berbeda angka
TF berbeda. Dapat disimpulkan bahwa fokus analisis daya dukung fisik adalah daya tampung kawasan dan daya tampung prasarana wisata (Gunn. C.A., 1994). Adapun rumus dari analisis daya tampung memiliki komponen sebagai berikut:

1. Kemampuan maksimal kawasan dan prasarana wisata (satuan orang/hektar) dan (satuan orang/meter persegi)

2. Jumlah wisatawan/bulan

3. Luas kemampuan pemanfaatan optimal (satuan orang/hektar) dan (satuan orang/meter persegi)

Apabila telah diketahui kemampuan optimal, maka dilanjutkan dengan mencari keputusan kapasitas kemampuan optimal dari angka jumlah kunjungan. Oleh karena itu, data pengunjung dengan karakter angka perbulan, maka harus dicari berapa jumlah pengunjung tertinggi dan terendah yang selanjutnya dibagi dengan bulan perolehan data, sehingga dapat ditentukan kapasitas kemampuan optimal berdasarkan jumlah pengunjung yang paling akhir.

Proses analisis daya dukung lingkungan, salah satunya adalah dengan menganalisis sensitivitas kawasan (Soemarwoto, 2004). Untuk kawasan pariwisata variabel penting yang seringkali digunakan, yaitu karakteristik fisik dasar dalam hal ini karakteristik kemampuan lahan. Menurut Soemarwoto (2004) kawasan dengan ekosistem yang rapuh tidak disyaratkan untuk kegiatan kepariwisataan.

Site atau tapak kepariwisataan alam yang berada di wilayah Yogyakarta Utara berada pada ekosistem. Ekosistem yang rapuh tersebut meliputi: kelerengan yang terjal, tanah yang tidak stabil karena mudah erosi dan longsor, angin kencang yang rentan menjadi bencana, gas beracun, dan lain sebagainya.

Ekosistem yang khas ini menjadikan kawasan tersebut perlu dianalisis sensitivitasnya, sehingga dapat memberikan gambaran bagi keputusan pengelolaan ke depan. Analisis sensitivitas dalam kajian daya dukung fisik, menggunakan pendekatan deskriptif kualitatif dengan masukan foto 
mapping. Variabel yang digunakan adalah variabel fisik dasar, berupa (1) kelerengan, (2) jenis tanah, dan (3) curah hujan. Pada tabel 1, dapat dilihat indikator untuk menilai sensitivitas kawasan dari segi karakteristik kemampuan lahan.

Tabel 1 Indikator Sensitivitas Kawasan Berdasarkan Kemampuan Lahan

\begin{tabular}{|c|c|c|}
\hline No. & Variabel Kemampuan Lahan & Indikator Kelayakan \\
\hline \multirow[t]{5}{*}{1.} & $\begin{array}{l}\text { Kelerengan } \\
\text { - } 0-8 \% \text { (datar) }\end{array}$ & Layak \\
\hline & - $8-15 \%$ (landai) & Layak \\
\hline & - $15-25 \%$ (agak curam) & Tidak Layak \\
\hline & - $25-45 \%$ (curam) & Tidak Layak \\
\hline & - $>45 \%$ (sangat curam) & Tidak Layak \\
\hline \multirow[t]{5}{*}{2.} & $\begin{array}{l}\text { Jenis Tanah (Stabilitas Tanah) } \\
\text { - Aluvial, Tanah Glei, Planosol, Hidromorf Kelabu, Laterite Air Tanah } \\
\text { (Tidak Peka Erosi) }\end{array}$ & Layak \\
\hline & - Latosol (Agak Peka Erosi) & Layak Bersyarat \\
\hline & - Brown Forest Soil, Non Calcie Brown, Mediteran (Kurang Peka Erosi) & Layak \\
\hline & - Andosol, Laterite, Grumosol, Pdsol, Podsolik (Peka Erosi) & Tidak Layak \\
\hline & - Regosol, Litosol, Orgasonol, Renzina (Sangat Peka Erosi) & Tidak Layak \\
\hline
\end{tabular}

Sumber: SK Mentan No. 683/Kpts/Um/1981,

Tabel 2 Indikator Sensitivitas Kawasan Berdasarkan Kemampuan Lahan

\begin{tabular}{l|l|l}
\hline No. & Variabel Kemampuan Lahan & Indikator Kelayakan \\
\hline \multirow{3}{*}{3.} & Curah Hujan (mm/hari hujan) & \\
& $\bullet-13,6 \mathrm{~mm} /$ hari (sangat rendah) & Layak Bersyarat \\
\cline { 2 - 3 } & $\bullet 13,6-20,7 \mathrm{~mm} /$ hari (rendah) & Layak Bersyarat \\
\cline { 2 - 3 } & $\bullet 20,7-27,7 \mathrm{~mm} /$ hari (sedang) & Layak \\
\cline { 2 - 3 } & $\bullet 27,7-34,8 \mathrm{~mm} /$ hari (tinggi) & Tidak Layak \\
\cline { 2 - 3 } & $\bullet \geq 34,8 \mathrm{~mm} /$ hari (sangat tinggi) & Tidak Layak \\
\hline
\end{tabular}

Sumber: SK Mentan No. 683/Kpts/Um/1981

Populasi pada penelitian ini adalah semua wisatawan baik asing maupun domestik yang berkunjung ke kawasan pusat kunjungan wilayah Yogyakarta Utara. Selanjutnya dari populasi ini akan dihitung jumlah sampel berdasarkan total populasi dalam satu tahun. Hasil perhitungan sampel ini dinilai representatif untuk menghasilkan kesimpulan akhir penelitian terkait dengan analisis yang digunakan.

Teknik pengambilan sampel yang dilakukan, dengan nonprobability sampling. Menurut Nazir (1983) nonprobability sampling adalah teknik pengambilan sampel yang tidak memberi peluang/kesempatan sama bagi setiap unsur atau anggota populasi untuk dipilih menjadi sampel. Untuk memfokuskan teknik nonprobability sampling, mekanisme yang dipilih adalah accidental sampling. Teknik ini dilakukan dengan mengambil data pada sampel berdasarkan faktor spontanitas. Artinya, siapa saja yang secara tidak sengaja/sengaja bertemu dengan peneliti di kawasan pusat kunjungan di wilayah Yogyakarta Utara, maka layak menjadi responden penelitian ini.

Teknik pengumpulan data ini dilakukan dengan 2 (dua) cara, yaitu data primer dan data sekunder Data primer adalah data yang diperoleh langsung dari sumbernya, yang diamati dan dicatat dengan melalui kegiatan penyebaran kuisioner, wawancara, dan pengamatan lapangan, sebagai berikut:

a) Penyebaran kuisioner Pengumpulan data melalui kuisioner yang disebarkan, dilakukan pada wisatawan/ pengunjung dengan tujuan untuk memperoleh data mengenai persepsi wisatawan pada tingkat kenyamanan berwisata.

b) Wawancara. Pengumpulan data dengan metode wawancara dilakukan 
pada pejabat pemerintah setempat yang terkait dengan kebijakan dan pengelolaan kawasan Taman Nasional Gunung Merapi (BTNGM).

c) Observasi/Pengamatan: untuk memperoleh informasi dan data kemapuan lahan.

d) Dokumentasi Foto: Pengumpulan data melalui dokumentasi foto selain sebagai bukti penelitian dan juga untuk kebutuhan analisis.

Data sekunder Data sekunder adalah data yang diperoleh dari survei instansi atau departemen yang berhubungan dengan materi penelitian. Adapun untuk instansi yang disurvei, meliputi:

a) Pengelola dan praktisi di obyek wisata alam.

b) Balai Taman Nasional Gunung Merapi (TNGM).

c) Badan Perencanaan dan Pembangunan Daerah Kabupaten Sleman

d) Instansi-instansi lain yang terkait.

e) Kajian dan penelitian terkait.

Desain ini sendiri memuat variabel, data dari variabel tersebut, jenis data, cara mendapatkan data, sumber data, dan metode analisis. Untuk lebih jelasnya dapat dilihat pada tabel di bawah ini.

Tabel 3 Desain Survai Kemampuan Fisik dan Lingkungan Optimal Kawasan Obyek Daya Tarik Wisata Alam

\begin{tabular}{|c|c|c|c|c|}
\hline TUJUAN & VARIABEL & JENIS DATA & SUMBER DATA & $\begin{array}{c}\text { METODE } \\
\text { ANALISIS }\end{array}$ \\
\hline \multirow[t]{2}{*}{$\begin{array}{l}\text { Mengetahui } \\
\text { Kemampuan } \\
\text { Fisik Optimal }\end{array}$} & $\begin{array}{l}\text { Jumlah wisatawan } \\
\text { (periode tahun 2008- } \\
\text { 2011) }\end{array}$ & Sekunder & $\begin{array}{l}\text { Dinas pariwisata } \\
\text { seni dan budaya } \\
\text { Kabupaten Sleman }\end{array}$ & \multirow{2}{*}{$\begin{array}{l}\text { Analisis } \\
\text { kemampuan } \\
\text { Optimal Kawasan } \\
\text { dan Prasarana } \\
\text { Wisata }\end{array}$} \\
\hline & $\begin{array}{l}\text { Luas pemanfaatan } \\
\text { optimal kawasan dan } \\
\text { prasarana wisata }\end{array}$ & $\begin{array}{l}\text { Sekunder dan } \\
\text { cek primer }\end{array}$ & $\begin{array}{l}\text { - BTN-TNGM } \\
\text { - Dinas Kehutanan } \\
\text { kabupaten Sleman }\end{array}$ & \\
\hline
\end{tabular}

Sumber: Analisis, Peneliti. 2011

\section{PEMBAHASAN}

Sektor kepariwisataan di wilayah Yogyakarta Utara merupakan hubungan aktivitas pariwisata Daerah Istimewa Yogyakarta dan Jawa Tengah. Peta kepariwisataan nasional, memperlihatkan bahwa potensi DIY menduduki peringkat ketiga setelah Bali dan Jakarta. Daerah Istimewa Yogyakarta memiliki keragaman objek wisata dengan karakter mantap dan unik seperti pariwisata alam, budaya, dan peninggalan sejarah. Hal ini ditunjang oleh kesiapan sarana penunjang wisata serta sumber daya manusia yang berkualitas.
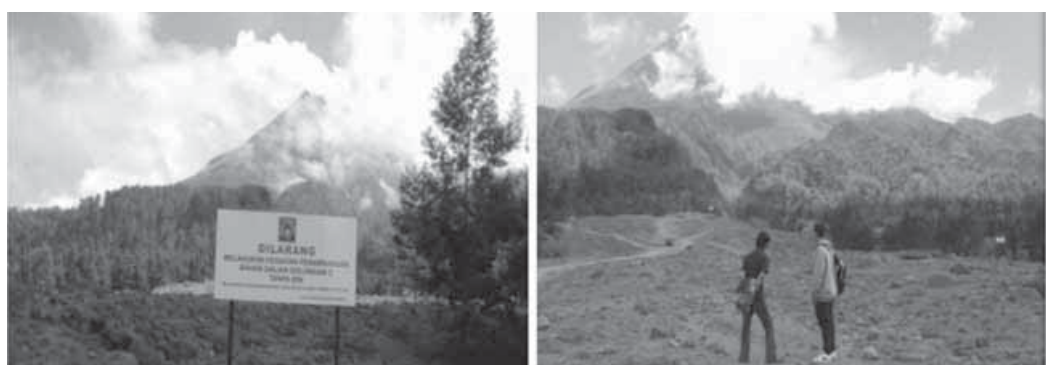

Gambar 3

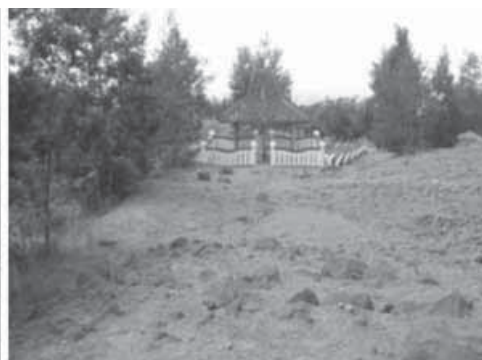

Kepariwisataan alam di kawasan lereng gunung Merapi

Sumber : Dokumentasi lapangan, 2010

Potensi-potensi wisata yang terletak di wilayah Yogyakarta bagian utara merupakan wilayah yang menawarkan seluruh suasana yang mencerminkan keaslian alam dan kehidupan 
sosial ekonomi. Potensi wisata yang terletak di Lereng Merapi bagian selatan merupakan suatu wilayah, sosial budaya, adat istiadat keseharian yang khas. Potensi ada dan ditawarkan sebagai daya tarik. Daya tarik tersebut bersifat asli, lokal, unik, indah yang berasal dari salah satu atau kombinasi dari lingkungan alam, kehidupan sosial ekonomi, dan budaya, arsitektur dan struktur tata ruang serta aspek historis.

Tabel 4 Potensi Kepariwisataan Alam Kabupaten Sleman

\begin{tabular}{l|l|l}
\hline No & \multicolumn{1}{|c|}{$\begin{array}{l}\text { Obyek Daerah } \\
\text { Tujuan wisata }\end{array}$} & \multicolumn{1}{c}{ Potensi wisata } \\
\hline 1 & $\begin{array}{l}\text { Kawasan Wisata } \\
\text { Kaliurang }\end{array}$ & $\begin{array}{l}\text { Panorama alam yang indah dan berhawa sejuk, camping ground, } \\
\text { taman rekreasi anak, penginapan, hutan wisata, tempat pertemuan dan } \\
\text { seminar, sarana olahraga dan wartel. }\end{array}$ \\
\hline 2 & $\begin{array}{l}\text { Kolam Renang Tlogo } \\
\text { Putri }\end{array}$ & $\begin{array}{l}\text { Diperuntukkan untuk rekresai keluarga yaitu kolam renang dengan } \\
\text { sumber air dari pegunungan. }\end{array}$ \\
\hline 3 & $\begin{array}{l}\text { TNGM dan Hutan } \\
\text { Wisata Prono Jiwo }\end{array}$ & $\begin{array}{l}\text { Taman Nasional Gunung Merapi sebagai penyedia jasa lingkungan } \\
\text { dan kepariwisataan merupakan kawasan konservasi alam sebagai } \\
\text { penyanggah kehidupan Provinsi DIY dan Hutan wisata dengan fasilitas } \\
\text { arena bermain, mushala, toilet, dan di dalamnya terdapat air terjun yang } \\
\text { disebut Tlogo Muncar. Sebagian masyarakat percaya jika mandi atau } \\
\text { cuci muka di air tejun ini akan awet muda. }\end{array}$ \\
\hline 4 & $\begin{array}{l}\text { Agro Wisata Salak } \\
\text { Pondoh }\end{array}$ & $\begin{array}{l}\text { Agrowisata Salak Pondoh dengan luas 27 ha tersedia fasilitas taman } \\
\text { rekresai, kolam pemancingan. Agrowisata terletak di jalur utama Candi } \\
\text { Borobudue dan Kaliurang, di Dusun Gadung, Bangunkerto, Turi, } \\
\text { Sleman }\end{array}$ \\
\hline 5 & $\begin{array}{l}\text { Panorama Kali Adem } \\
\text { dan kawasan wisata } \\
\text { kaliadem }\end{array}$ & $\begin{array}{l}\text { Kawasan wisata Kaliadem sebelumnya merupakan kawasan wisata } \\
\text { alam dengan panorama indah Gunung Merapi dan fasilitas camping } \\
\text { ground. Setelah erupsi Gunung Merapi 2010, kawasan yang sekarang } \\
\text { ditutup material vulkanik ini direncanakan menjadi kawasan wisata } \\
\text { erupsi dan pendidikan. Kunjungan ke objek tersebut dipandu tim SAR. }\end{array}$ \\
\hline
\end{tabular}

Sumber: Pengamatan lapangan, 2012

Rekapitulasi kunjungan wisatawan domestik memuat data kunjungan wisatawan (pengunjung) domestik yaitu data kunjungan mulai tahun 2008 sampai dengan tahun 2011. Berdasarkan data 3 (tiga) tahun tersebut, maka dapat dilihat trend kunjungan per bulan berupa rata-rata jumlah kunjungan. Untuk lebih jelasnya mengenai jumlah pengunjung per bulan dan rata-rata kunjungan per bulan di wilayah Yogyakarta utara dapat dilihat pada tabel dibawah ini.

Tabel 5 Jumlah Wisatawan Nusantara ke Desa Wisata di Yogyakarta Utara selama 1 tahun (12 Bulan) Pasca-Erupsi

\begin{tabular}{l|l|l|l|l|l|l|l|l|l|l|l|l|l} 
CANDI & Jan & Feb & Mar & Aprl & Mei & Jun & Juli & Ags & Sept & Okt & Nov & Des & Juml \\
\hline
\end{tabular}

\begin{tabular}{l|l|l|l|l|l|l|l|l|l|l|l|l|l}
\hline KEPARIWISATAAN ALAM DI WILAYAH YOGYAKARTA UTARA & \multicolumn{10}{l}{ YTA } \\
\hline Kaliurang & 63140 & 33632 & 47381 & 44046 & 56216 & 68640 & 72123 & 53820 & 37583 & 93774 & 43401 & 52826 & 666582 \\
\hline Lava Tour & 8075 & 2807 & 3067 & 2138 & 2457 & 3191 & 3496 & 3690 & 1801 & 8158 & 2330 & 3384 & 44594 \\
\hline Agrowisata & 1778 & 936 & 1188 & 1037 & 1748 & 1272 & 1092 & 1151 & 947 & 1630 & 1073 & 1760 & 15612 \\
\hline Merapi Golf & 2323 & 1659 & 1821 & 2312 & 2007 & 2124 & 2149 & 2914 & 1559 & 1669 & 2087 & 2326 & 24950 \\
\hline Jumlah Total & 71260 & 36467 & 50502 & 46243 & 58771 & 72051 & 75765 & 57674 & 39494 & 102003 & 45781 & 56253 & 712264 \\
\hline
\end{tabular}

Sumber: Dinas Kebudayaan dan Pariwisata, 2012

Posisi strategis kabupaten Sleman yang terletak di antara Provinsi DIY dan Jawa Tengah menjadikannya sebagai channel untuk aktivitas pariwisata DIY- Jawa Tengah. Bandara Adisutjipto berada di Kabupaten Sleman mempermudah akses wisatawan ke DIY-Jawa Tengah, khususnya Kabupaten Sleman. Kemudahan akses ini menjadikan kabupaten Sleman sebagai pusat aktivitas pariwisata. 
Peluang ekonomi ini ditangkap oleh pelaku-pelaku pariwitasa di Kabupaten Sleman dengan layanan wisata berupa pengembangan destinasi wisata, penyediaan sarana prasarana wisata, dan lain-lain. Pariwisata di Kabupaten Sleman mengalami perkembangan pesat seiring dengan perhatian pemerintah daerah terhadap sektor kepariwisataan. Hal tersebut berdampak terhadap jumlah kunjungan wisatawan terhadap obyek-obyek wisata.

Berdasarkan hasil observasi yang dilakukan, diketahui bahwa konsentrasi pengunjung (pusat kunjungan) berada pada beberapa kawasan-kawasan tertentu. Konsentrasi kunjungan tersebut meliputi: (1) kawasan wisata Kaliurang, (2) lava tour, (3) Merapi Golf, (4) agrowisata, dan (5) desa wisata. Berdasarkan hasil observasi ini, berikut akan ditampilkan rekapitulasi data kunjungan pada bulan. Setelah pascaerupsi 2010 rekapitulasi data kunjungan merupakan data sekunder tahun terakhir (2011) yang diperoleh dari Dinas Pariwisata, Seni dan Budaya Kabupaten Sleman.

Apabila daya dukung fisik diperhitungkan, maka dapat diperoleh angka berapa luas areal yang dibutuhkan bagi wisatawan untuk secara leluasa yang dapat memuaskan dalam berwisata. Berdasarkan analisis daya dukung fisik optimal maka kebutuhan area untuk aktivitas wisatawan berdasarkan faktor pemulihan atau keterbalikan (Turnover Factor /TF) maka akan di peroleh jenis aktivitas dan luasan yang berbeda dan menghasilkan angka RF yang berbeda .

Tabel 6 Toleransi Kapasitas Fisik dan Lingkungan Optimal di Kawasan Wisata Yogyakarta Utara

\begin{tabular}{|c|c|c|c|c|c|c|c|c|}
\hline \multirow{2}{*}{ No } & \multirow{2}{*}{ Tahun } & $\mathbf{A}$ & \multirow{2}{*}{ Jumlah wisatawan } & \multirow{2}{*}{ D } & \multirow{2}{*}{$\begin{array}{l}\text { CD } \\
\mathrm{hr} / \mathrm{th}\end{array}$} & \multirow{2}{*}{$\begin{array}{c}\mathrm{V} / \mathrm{a} \\
\text { peng/m2 }\end{array}$} & \multirow[t]{2}{*}{ RF } & \multirow[t]{2}{*}{ TF } \\
\hline & & luas area & & & & & & \\
\hline 1 & 2003 & 15.0 & $2,721,872.0$ & 907.0 & 52.0 & 7.0 & 120.0 & 1.0 \\
\hline 2 & 2004 & 16.0 & $3,033,227.0$ & 907.0 & 52.0 & 7.0 & 120.0 & 1.0 \\
\hline 3 & 2005 & 17.0 & $2,525,138.0$ & 907.0 & 52.0 & 7.0 & 120.0 & 1.0 \\
\hline 4 & 2006 & 18.0 & $2,343,916.0$ & 907.0 & 52.0 & 7.0 & 120.0 & 1.0 \\
\hline 5 & 2007 & 19.0 & $2,755,421.0$ & 907.0 & 52.0 & 7.0 & 120.0 & 1.0 \\
\hline 6 & 2008 & 20.0 & $3,002,057.7$ & 907.0 & 52.0 & 7.0 & 120.0 & 1.0 \\
\hline 7 & 2009 & 20.0 & $3,117,199.2$ & 907.0 & 52.0 & 7.0 & 120.0 & 1.0 \\
\hline 8 & 2010 & 20.0 & $3,232,340.7$ & 907.0 & 52.0 & 7.0 & 120.0 & 1.0 \\
\hline 9 & 2011 & 25.0 & $3,347,482.2$ & 907.0 & 52.0 & 7.0 & 120.0 & 1.0 \\
\hline
\end{tabular}

Sumber : survei data diolah, 2009

Dari análisis tabel di atas, dapat di perhitungkan bila suatu areal untuk kegiatan kepariwisataan (tahun 2011) yang sebagian besar memilih objek daya tarik wisata alam

sebesar 3.347.482,2, rata-rata membutuhkan waktu 52 hari dalam setahun yang dapat dipergunakan untuk kegiatan tertentu. Untuk itu, daya dukung fisik (PCC) yang diperoleh rata-rata (nilai $\mathrm{V} / \mathrm{a}$ ) dan luas area yang di butuhkan oleh wisatawan untuk berwisata dengan tetap memperoleh kepuasan sebesar $25.000 \mathrm{~m}^{2}$ atau 7,0 pengunjung per- $\mathrm{m}^{2}$.

Areal yang di pergunakan tersebut di konversi dengan jumlah wisatawan yang mengunjung wilayah Yogyakarta utara dan memilih objek dan daya tarik wisata alam sebesar 7.226 atau hampir $56 \%$ dari jumlah wisatawan yang berkunjung pada tahun tersebut (2011), maka luasan yang dibutuhkan untuk kegiatan berwisata sebesar $14.000 \mathrm{~m}^{2}$ dan hanya untuk satu kegiatan berwisata misalnya berkemah dan berekreasi dan lainlain.

Penghitungan dan penganalisisan kemampuan fisik secara optimal difokuskan pada proses asosiasi antara pembagian jumlah pengunjung dengan luasan optimal pemanfaatan kawasan. Selanjutnya, dari angka tersebut dapat ditentukan daya tampung optimal dengan mekanisme pengurangan angka jumlah pengunjung dengan daya tampung maksimal.

Selanjutnya, apabila telah diketahui daya tampung optimal, maka dilanjutkan 
dengan mencari keputusan kapasitas kemampuan fisik optimal dari angka jumlah kunjungan. Untuk mengetahui data pengunjung dengan karakter angka perbulan, maka harus dicari berapa jumlah pengunjung tertinggi dan terendah yang selanjutnya dibagi dengan bulan perolehan data, sehingga dapat ditentukan kapasitas daya dukung kemampuan fisik optimal berdasarkan jumlah pengunjung yang paling akhir.

Terkait dengan hasil analisis, keputusan yang diambil; dihasilkan melalui proses analisis ideal dengan kombinasi pada faktor etika kelenturan kebijakan lingkungan. Artinya, setelah dihasilkan angka daya tampung pengunjung pada suatu kawasan, masih perlu dilanjutkan dengan tahap kelenturan. Tahap kelenturan ini adalah mempertimbangkan nilai tertinggi dan terendah pada bulan perolehan data, sehingga keputusan tidak menjadi kaku.

Wilayah-wilayah dengan kunjungan zero (0) per-tahun seperti desa-desa wisata yang terdapat di lereng selatan merapi dalam satuan bulan merupakan wilayah yang mempunyai daya tampung wilayah dengan kelenturan tinggi. Data hasil analisis di wilayah barat terlihat pada tabel di bawah ini. Keputusan wilayah-wilayah yang menjadi pusat kunjungan adalah sebagai berikut:

a. Wilayah hutan wisata Kaliurang, diputuskan daya tampung optimal jumlah pengunjung 1.758 orang/hektar/ bulan dan 21.094 orang/hektar/tahun.

b. Lava tour, diputuskan daya tampung optimal jumlah 1.504 orang/hektar/bulan. dan 158.119 orang/hektar/tahun.

c. Wilayah panorama Kaliadem, diputuskan daya tampung optimal jumlah pengunjung 1.758 orang/hektar/ bulan dan 21.094 orang/hektar/tahun.

d. Labuhan Merapi, diputuskan daya tampung optimal jumlah pengunjung 13.177 orang/hektar/bulan dan 158.119 orang/hektar/tahun.

e. Wilayah Kalikuning, diputuskan daya tampung optimal jumlah pengunjung 6.822 orang/hektar/bulan dan 81.862 orang/hektar/tahun. f

f. Wilayah agrowisata bahwa diputuskan daya tampung optimal jumlah pengunjung adalah 87 orang/hektar/ bulan dan 16.685 orang/hektar/tahun.

Tabel 7 Hasil Analisis Daya Tampung Optimal dalam Satuan Bulan dan Tahun

\begin{tabular}{|c|c|c|c|c|c|}
\hline No & Objek Wisata & Luas tempat wisata & Optimal & Per Tahun & Per bulan \\
\hline 1 & Hutan Wisata Kaliurang & 85 & 1597 & 21094 & 1758 \\
\hline 2 & Kolam Renang Tlogo Putri & 2 & 1703 & 32161 & 2680 \\
\hline 3 & Gardu Pandang Boyong & 1,12 & 912 & 11817 & 985 \\
\hline 5 & Kantor Pengamatan Merapi & 1,0 & 1810 & 0 & 0 \\
\hline 6 & Bumi Perkemahan & 12 & 1818 & 8029 & 669 \\
\hline 7 & Hutan Percobaan Kaliurang & 10 & 1815 & 0 & 0 \\
\hline 8 & Tlogo Nirmolo & 5 & 238 & 18051 & 1504 \\
\hline 9 & Lava Tour & 15 & 1460 & 158119 & 13177 \\
\hline 10 & Panorama Vulkanik & 10 & 1703 & 81862 & 6822 \\
\hline 11 & Sistim Pemantauan Merapi & 1,15 & 1581 & 4342 & 362 \\
\hline 13 & Wisata Trekking & 8 & 1703 & 32161 & 2680 \\
\hline 14 & Taman Rekreasi Kaliurang & 15 & 912 & 11817 & 985 \\
\hline
\end{tabular}

Sumber: Data penelitian diolah, 2012

Hasil analisis daya tampung optimal dalam satuan bulan dan tahun di wilayah barat dan timur hampir sebagian besar termasuk wilayah Taman Nasional Gunung Merapi. Hasil analisis daya tampung optimal di wilayah tersebut mengindikasikan adanya struktur pengembangan kepariwisataan. 
Tabel 8

Daya Tampung Optimal dalam Satuan Bulan dan Tahun di Wilayah Timu

\begin{tabular}{l|l|l|l|l|l}
\hline \multicolumn{1}{c|}{ No } & \multicolumn{1}{|c|}{ Objek Wisata } & \multicolumn{1}{c|}{ Luas } & \multicolumn{1}{c}{ Optimal } & \multicolumn{1}{c}{ Per Tahun } & \multicolumn{1}{c}{ Per bulan } \\
\hline 1 & Panorama Kaliadem & 12 & 1597 & 21094 & 1758 \\
\hline 2 & Merapi Golf & 15 & 1703 & 32161 & 2680 \\
\hline 4 & Gua Pontheng & 1,5 & 608 & 14630 & 1219 \\
\hline 5 & Jambu, Kepuhharjo & 129 & 1810 & 0 & 0 \\
\hline 6 & Kinahrejo & 295 & 1818 & 8029 & 669 \\
\hline 7 & Pentingsari & 198 & 1815 & 0 & 0 \\
\hline 8 & Gua Jepang & 1,15 & 238 & 18051 & 1504 \\
\hline 9 & Labuhan Merapi & 5 & 1460 & 158119 & 13177 \\
\hline 10 & Kali Kuning & 15 & 1703 & 81862 & 6822 \\
\hline 11 & Bumi Perkemahan & 7,5 & 1581 & 4342 & 362 \\
\hline
\end{tabular}

Sumber: Data penelitian, diolah, 2008

\section{ANALISIS DAYA DUKUNG LINGKUNGAN}

Berdasarkan hasil analisis peta kontur kawasan Kaliurang dan lava tour sebagai pusat kunjungan, diperoleh informasi kelerengan yang variatif. Karakter yang variatif ini, meliputi: (1) kelerengan lahan kondisi datar $(0-8 \%)$ yang dominan berada di panorama kaliadem dan merapi Golf; (2) kelerengan lahan kondisi landai (8-15\%) di sekitar desa wisata Pentingsari di sebelah utara; (3) agak curam (15-25\%) di sekitar Taman Rekreasi Kaliurang, Kalikuning, dan Bumi perkemahan; dan (4) curam (25-45\%) hutan wisata Kaliurang, wisata trekking, Lava Tour, dan Panorama Vulkanik.

Peta sensitivitas kawasan Cemorolawang, memberi informasi untuk keputusan sensitivitas kawasan yang variatif. Keputusan tersebut adalah sebagai berikut:

1) Kelerengan lahan kondisi datar (0$8 \%$ ), yaitu layak untuk pemanfaatan kawasan wisata alam karena memiliki nilai sensitivitas yang rendah, walaupun jenis tanah berpasir dan curah hujan relatif tinggi selama 4 bulan (DesemberMaret).

2) Kelerengan lahan kondisi landai (8$15 \%)$, yaitu layak untuk pemanfaatan kawasan wisata alam karena memiliki nilai sensitivitas yang rendah, walaupun jenis tanah berpasir dan curah hujan relatif tinggi selama 4 bulan (DesemberMaret).

3) Kelerengan agak curam (15-25\%), yaitu tidak layak untuk pemanfaatan kawasan wisata karena sudah masuk dalam lingkup nilai sensitivitas sedang. Pertimbangannya dikarenakan keterbatasan dari jenis tanah yang bertipikal sangat peka erosi (regosol) dan dipengaruhi oleh curah hujan yang relatif tinggi selama 4 bulan (DesemberMaret).

4) Kelerengan curam (25-45\%), yaitu tidak layak untuk pemanfaatan kawasan wisata karena masuk dalam lingkup nilai sensitivitas tinggi. Lebih lanjut, juga dengan pertimbangan keterbatasan dari jenis tanah yang bertipikal sangat peka erosi (regosol) dan dipengaruhi oleh curah hujan yang relatif tinggi selama 4 bulan (Desember-Maret).

\section{SIMPULAN}

Kapasitas fisik merupakan kemampuan tertentu pada suatu daerah untuk menerima wisatawan atau jumlah wisatawan maksimal yang dapat memanfaatkan suatu kawasan tanpa menimbulkan penurunan kualitas lingkungannya. Kemampuan fisik optimal kawasan wisata dapat menentukan batas toleransi kapasitas yang masih memungkinkan secara fleksibel sehingga terpenuhinya tingkat keleluasaan dan kepuasan bagi wisatawan pada saat melakukan aktivitas.

Berdasarkan analisis kapasitas fisik kebutuhan area untuk aktivitas wisatawan, yaitu faktor pemulihan atau keterbalikan (Turnover Factor /TF) telah di peroleh jenis aktivitas dan luasan yang berbeda 
serta berbanding lurus dengan nilai (1.2) sebagai kemampuan fisik secara optimal. Kapasitas fisik yang diperhitungkan ini telah diperoleh angka luasan areal yang dibutuhkan bagi wisatawan untuk secara leluasa dan memuaskan dalam berwisata. Wilayah Yogyakarta Utara masih mempunyai kapasitas fisik untuk tingkat keleluasaan berwisata terutama berwisata alam.

Berdasarkan analisis daya dukung lingkungan kelerengan lahan kondisi datar (0-8\% s/d 15\%) terutama di wilayah tengah dan timur layak untuk pemanfaatan kawasan wisata alam dan mempunyai kapasitas fisik yang baik karena memiliki nilai sensitivitas yang rendah, walaupun jenis tanah berpasir dan curah hujan relatif tinggi selama 4 bulan (Desember-Maret) dalam satu tahun setelah erupsi 2010.

Kelerengan agak curam (15-45\%), tidak layak untuk pemanfaatan kawasan wisata karena sudah masuk dalam lingkup nilai sensitivitas sedang. Pertimbangannya dikarenakan keterbatasan dari jenis tanah yang bertipikal sangat peka erosi (regosol) dan dipengaruhi oleh curah hujan yang relatif tinggi selama 4 bulan (DesemberMaret), setelah erupsi 2010.

\section{DAFTAR PUSTAKA}

Colinvaux, P. 1986 . Ecology . John Wiley dan Sons. New York.

Chafid Fandeli dan Muhammad. 2009. Prinsip-Prisip Dasar Mengkonservasi Lanskap. University of Gadjah Mada, Yogyakarta.

Douglas, R.W. 1975. Forest Recreations. Second Edition. Pergamon Press Inc. New York.

Eplerwood, M. 1999. Successful Ecotourism Business. The Right Approach. World Ecotourism Conference. Kota Kinabalu. Sabah.
Gunn, C.A. 1994. Tourisme Planning Bassic. Concept. Casees London: Taylor dan Francis Ltd.

Hall, C.M. dan Page, S.J. 1999. The Geography of Tourism and Recreation Environment. Place dan Space. New York, Routledge.

Inskeep. E. 1991. Tourism Planning an Intergrated and Sustainable Development Approach. New York: Van Nostrand Reinhold.

Kantor Kementrian Lingkungan Hidup. (1997) Undang-Undang Republik Indonesia Nomor 23 Tentang Pengelolaan Lingkungan Hidup (UNDANG-UNDANG PLH). Jakarta.

Maryani. E. 2004. "Struktur Keruangan Pariwisata di Kawasan Inti Bandung Raya". Disertasi. Program Pascasarjana Universitas Gadjah Mada Yogyarta. (tidak diterbitkan) .

Muhammad. 2010. Pembangunan Kepariwisataan Berkelanjutan di Wilayah Yogyakarta utara Sebelum Erupsi 2010 (Interaksi Masyarakat Sekitar Taman Nasional Gunung Merapi). Sekolah Pascasarjana Universitas Gadjah Mada Yogyakarta. (tidak diterbitkan).

Nazir, M. 1983. Metode Penelitian. Ghalia Indonesia. Jakarta.

Pearce, D.G. 1998. Tourism Development . John Willey \& Sons Inc. New York.

Soemarwoto. O. 2004. “Ekologi, Lingkungan Hidup dan Pembangunan. Djambatan. Jakarta.

Wiratno. Dkk, 2000. Refleksi konservasi dan Implikasi bagi Pengelolaan Taman Nasional. The Gibbon Foundation Indonesia, PILI-NGO Movement, Jakarta. 